\title{
PROFITS: A CASE OF EXCHANGE RATE VOLATILITY
}

\author{
Gatut L. Budiono', Agnesya Firdayasa ${ }^{2}$ \\ Universitas Pancasila182gatutbudiono@gmail.com ${ }^{1}$,firdacha@yahoo.co.id ${ }^{2}$
}

\begin{abstract}
The purpose of this research was to measure the effect of exchange rate volatility on the companies' profit in food and beverages sub sector with revenue and expenses as an intervening. The analysis technique used in this research was regression and path analysis. The financial statement and middle exchange rate of first quarter of 2012 to 2015 third quarter IDX and BI secondary data was incorporated in the research. These research result showed that the exchange rate volatility may affect companies' profit in food and beverages sub sector either directly or indirectly.
\end{abstract}

Keywords: exchange rate volatility, profit, revenue, expenses.

Abstrak: Tujuan dari penelitian ini adalah untuk mengukur pengaruh volatilitas nilai tukar pada keuntungan perusahaan dalam sub sektor makanan dan minuman dengan pendapatan dan beban sebagai intervensi. Teknik analisis yang digunakan dalam penelitian ini adalah regresi dan analisis jalur. Laporan keuangan dan kurs tengah kuartal pertama 2012-2015 kuartal ketiga BEI dan BI data sekunder didirikan dalam penelitian. Hasil penelitian ini menunjukkan bahwa volatilitas nilai tukar dapat mempengaruhi laba perusahaan dalam makanan dan minuman sub sektor baik secara langsung maupun tidak langsung.

Kata kunci: volatilitas nilai tukar, laba, pendapatan, pengeluaran.

\section{INTRODUCTION}

The volatility of the exchange rate of a country's currency against foreign currencies is relatively unstable. Changes in the currency exchange rate movements also occurred on the Indonesian Rupiah has appreciated or depreciated against the US Dollar. Based on data from Bank Indonesia rupiah was depressed sharply to levels Rp15.123,00 per US dollar or depreciated by 0.91 per cent on 23 September 2015 and began to strengthen to the level Rp14.882,00 or 1,47 per cent on October 6, 2015,

The movement of the exchange rate fluctuating can affect the amount of profit obtained by the company. Based on research conducted by Requeena and Walker (2005: 231) in the journal entitled "The impact of exchange rate Fluctuation on profit margins: The UK Car Market" explaining that corporate profits are affected by changes in currency exchange rates. Rupiah middle exchange rate movements against the US dollar shows that during January 2011 to October 2015 the rupiah experience erratic changes from time to time. The change can be observedin the chart between September 2012 and 2014 were on average moved lower to fall within the range of 12000. The movement of the rupiah weakened severe enough that the range of 14000 to 2015 in September. In October 2015 the exchange rate rebounded to the level of 13700. Changes in exchange rates may also have an impact on exports and imports. On the export side, the changes can give usan advantage over foreign sales activities. However, on the import side, the changes will have 
an impact on changes in the prices of imported products in Indonesia, where the rupiah weakening in the rupiah prices of imported products will increase.

The movement of currency exchange rates had an impact of the number of changes in revenues and expenses, the company mainly export and import perpetrators with foreign currency transactions. For export-oriented company, it can provide benefits for export sales volume greater than the volume of domestic sales in order to increase the profits of export sales.

According to Tambunan (2015: 76) for importers on the condition of the rupiah weakened if a company in Indonesia every month to import the main raw material in large quantities, it can be imagined how much extra expense of importers are experiencing a decrease in profits or the difference between the results sales and production costs as well as import costs. But according to Kewal (2012) when the value of the rupiah against the US dollar strengthening will lower production costs, especially the cost of imported raw materials will also positively impact the company's earnings.

Changes in exchange rates have affected changes in acceptance of corporate profits. If the exchange rate of the Rupiah against the US Dollar weakened then it can lead to increased acceptance of corporate profits of exporters. Whereas, if the currency exchange rate Rupiah strengthened, it can make a profit decline in the acquisition of the company. This has happened because if the rupiah weakens, the greater the amount of amount received by the company to the US Dollar, and vice versa happens if the exchange rate of the rupiah have strengthened.

Several studies have been conducted to analyze the effect of changes in currency exchange rates against the profit of companies, one of which has been done by Baggs, Beaulieu, and Fung (2008) in the journal entitled "The Impact of Real Exchange Rate Movements on Service Sector Firms" has been found implications significant fluctuations in exchange rates significantly affect the amount of profitability of the company.

In this study, has involved several private companies sub-sectors of food and beverages export activities in its business, and the use of foreign currency in their transactions directly so there is a link between the movement of the exchange rate with the profit of the company.

The research problem, among others, the rupiah against the US dollar is one factor to be considered by the company in its business activity. The movement of the exchange rate has been fluctuating could affect the company's business activities, especially in companies that often make transactions using foreign currency. The movement of the exchange rate has affected the revenues and expenses of companies that do export and import activities. Effect of changes in the exchange rate has affected directly and indirectly. At the time of the rupiah strengthened to the benefit on the import side due to the cost incurred by the company in importing raw materials will be less and vice versa if the rupiah weakens. For exporting companies, the exchange rate weakened will benefit because the income from export sales will increase and vice versa when the rupiah strengthened so it can indirectly affect the profitability of the company.

This study has discussed the movement of the exchange rate of the rupiah that affect company profits sub-sectors of food and beverages, have been conducted in the period of 2012 first quarter and 2015 third quarter due to the limitations of the data presented by the Indonesia Stock Exchange, as well as focusing on the movement of the rupiah against the US dollar, operating revenues, operating expenses and net income of the current period. Discussion to identify movement of the rupiah against the dollar and the effect on net 
income directly and indirectly. Company research object is a company engaged in the food and beverage sub-sector which exports processed foods of marine products. Exchange rates have been used in this study is the exchange rate of Bank Indonesia that ended in late perode current run.

Formulation of the problem whether there is influence of the movement of the exchange rate directly to the company's profit? Whether there is influence of the movement of the exchange rate directly to the company's revenue? Whether there is influence of the movement of the exchange rate directly to the company's operating costs? Whether there has been a direct influence operating revenues of corporate profits? Whether there has been a direct influence operating expenses of corporate profits? Whether there is influence of the movement of the exchange rate indirectly to the company's profit through revenue? Whether there is influence of the movement of the exchange rate is not directly on corporate earnings through expense?

The research objective was to determine whether there has been a direct influence and how much influence Rupiah exchange rate changes on corporate earnings. Whether there is a direct influence and how much influence change in value of the rupiah against the company's operating revenues. Whether there is a direct influence and how much influence changes in the value of the Rupiah against the company's operating costs. Is there a direct influence and how much influence the revenues of corporate profits. Whether there is a direct influence and how much influence the operating cost burden on corporate earnings. Whether there is indirect influence and how much influence changes in value of the rupiah against the profits received by the companies by revenue. Whether there is indirect influence and how much influence changes in value of the rupiah against the profits earned by the company over the costs.

This research has been beneficial in practice to apply the knowledge and theories about some things that can affect the company's earnings so it can be comparing between the reality of the matter with the theories and expected to increase knowledge and insight into the science of business management. Has been able to be material information about the effect of exchange rate movements against the perpetrators of corporate profits in exports that may be considered decisions, maximize profits. This research has been useful as a source of information for investors for consideration decision to invest. This study was expected to be used as reading material as well as an insight to add additional information for the community readers who want to learn about the changes in the value of the rupiah against the US dollar and its impact on revenues, expenses and profitability of the company.

\section{THEORITICAL REVIEW}

Currencyexchange according to Mankiw (2006: 128) is the rate agreed by residents of countries trade with each other. In addition to these definitions, Sukirno (2012: 397) argues that the foreign exchange rate reflects the price or value of a country's currency expressed in another country's currency. Foreign exchange rates have been defined as the amount of domestic money is needed, the amount of rupiah that is needed to obtain one unit of foreign currency. Several other definitions of the exchange rate or exchange: Another understanding on the exchange rate or the rate stated by Frank J. Fabozzi and Franco Modigliani (in Ekananda, 2014: 168) "An exchange rate is defined as the amount 
of one currency that can be exchanged per unit of another currency, or the price of one currency in terms of another currency ". Cornelius Lucas (in Ekananda, 2014: 168) states that "an exchange rate is the price of one currency in terms of another"

It has been concluded that the exchange rate is the price of a country's currency against the currencies of other countries, as the amount of money a particular country's currency that can be exchanged to acquire one unit of another country's currency.

Currency exchange rates have fluctuated, appreciation and depreciation. Appreciation is the strengthening of the exchange rate of a country's currency against the currencies of other countries because of the forces of supply and demand for money in the free market, as a result of currency appreciation makes goods prices become more expensive and the price of imports become cheaper. Depreciation, impairment of a country's currency exchange rate against the currencies of other countries because of the forces of supply and demand for money in the free market.

As a result of the depreciation of making the price of goods from overseas become cheaper and import prices for domestic parties become more expensive. According Manullang (2008) changes that occur in the exchange rate impact on exports and imports. When a country's currency depreciates, exports to foreign parties are becoming increasingly expensive, while the country's imports become more expensive. Appreciation otherwise adversely affect the price of products for the country's foreign parties are becoming increasingly expensive, while the price of imported for domestic residents become cheaper than before.

According Sukirno (2012: 402) people's desire has affected their consumption pattern. Then change the public taste had changed their consumption patterns towards goods produced domestically and imported. Improvement in the quality of goods in the country has led to a desire to import less and can also increase exports. While the improvement of the quality of imported goods has caused people's desire to import increases. These changes will affect the demand and supply of foreign exchange.

Basically speculation and rumors in the community has affected the demand and supply of foreign currencies affecting foreign exchange (Hady, 2012: 116). The same opinion was also shown by Patel et.al in the journal entitled "Factors affecting currency exchange rates, economical formulas and prediction models" revealed that the rumors and the role of speculators can affect demand and supply of currencies, such as the example in the Indian state if speculators believe Rupee India will increase in the near future, they will begin to demand Indian Rupee now in order to gain advantage in the future, thereby causing an increased demand for the Indian Rupee and the Indian Rupee value increases.

In general, the company's main goal is to generate maximum profits. Some understanding of the profit economists have an opinion as according Samryn (2014: 43) profit or loss is the result of cost reductions on the income of the company to generate profits if revenue exceeds expenses and otherwise the excess will result in a loss if the cost is greater than the total revenue. In this study used income is net income. According to Hery (2015: 40-41) disclose the net profit derived from the transaction revenues, expenses, gains, and losses. Profit is derived from the difference between the input power source such as revenue and profit, with resources out like a burden and losses over a given period. According Suwardjono (in Ekawati, 2012: 18) profit is defined as a reward the company's efforts to produce goods and services means that profit is the excess of revenues over costs. According Soemarsono S.R (in Ekawati, 2012: 19) earnings is influenced by several factors as follows: Expenses arising from the acquisition or processing of a product and 
the service will affect the selling price of products. Cost of goods or services will affect the volume of sales of products or services. The large volume of sales affect the production volume of products or services, then the volume of production will affect the size of the production costs.

Effect of currency rate volatility on earnings. The movement of the exchange rate is one factor that can affect earnings. This was evidenced by some journals do research. The impact of exchange rate changes quite noticeably for companies perpetrators of import and export, if the exchange rate moved lower then make a profit decline for the company importing and vice versa if the exchange rate strengthened. According to Baggs, Beaulieu, and Fung (2008) in the journal stated that there is a significant correlation of exchange rate fluctuations affect the company's profits. For exporting companies if the exchange rate moved lower profit improvement will benefit the company.

In addition, according to research conducted by Fitri (2008) suggests that changes in the exchange rate significant and positive impact on net income. This study focused on the company's net profit, means that exchange rate movements have affected the net profit obtained by the company.

Effect of exchange rate volatility on earnings through income. It was inevitable that the movement of the exchange rate is one factor that affects the profitability of the company, but before it affects the profit of exchange rate movements had an indirect effect through operating revenues. Revenues are inflows of other assets or increase of the assets or settlement of liabilities of the entity, or a combination of both, from the delivery of goods, provision of services, or any other activity which is the main operating company or central operations. (Hery, 2015: 41). This study was used operating revenues. According to research conducted by the Prime et.al (2012) weakening rupiah exchange rate against the US dollar significantly affect the increase in export value means weakening of the exchange rate impact on increasing revenue and profit due to an increase in export value. It has shown the company's profitability can also be indirectly affected by the company's revenue.

Effect of exchange rate changes on earnings through cost burden. Cost was an outflow of assets or any other use of the asset or liability emergence entity or a combination of both, caused by delivery or manufacture of goods, provision of services, or any other activity which is the main operating company or a central operations (Hery, 2015: 41). In this study, the cost is the cost of business. According Horisson (in Efilia 2014: 3) costs continue to be issued by an entity that is directly related to the sales. Changes in exchange rate instability could indirectly affect the costs incurred by the company. According to Rachman (2012: 9) for companies that import the declining value of the rupiah against foreign currencies increases the cost of imported raw materials and equipment needed so that the company can increase production costs and vice versa for companies that export. It shows that the rise and fall of the rupiah exchange rate movements will have an impact on the increase or decrease in the cost incurred by the company.

Some of the relevant research results. Research conducted by Fitri (2008) showed that changes in the exchange rate significant and positive impact on the net income with a 95\% confidence level. In addition, research conducted by Ekawati (2012) showed that in partial exchange rates significant effect on earnings or profit companies with a percentage of $87.8 \%$. Theories about the effect of exchange rate movements and profits through research conducted by Ainul Fitri (2008) showed that changes in the exchange rate 
significant and positive impact on the net income with a 95\% confidence level. In addition another statement from the same research was done by Baggs, Beaulieu, and Fung (2008) in the journal discover the implications of significant fluctuations in exchange rates significantly affect the amount of corporate profits. The theory is based on the hypothesis of this study are thought to directly influence the movement of the exchange rate on profits. H1: There is a significant relationship between exchange rate movements directly on corporate earnings.

Theories about the effect of exchange rate movements and operating income results of research by the Prime et.al (2012) that there has been a weakening of the rupiah against the US dollar significantly affect the increase in the value of exports, which means that the weakening of the exchange rate may have an impact on the increase in operating revenues and corporate profits due to an increase in export value. The theory is based on the hypothesis studies suggest there is a direct influence of the movement of the rupiah against business income. H2: There is a significant relationship between exchange rate movements directly to the company's operating revenues.

Theories about the effect of exchange rate movements and cost of business results of the study by Rachman (2012: 9) and Suryanto T (2016) has stated that companies that import the declining value of the rupiah against foreign currencies increases the cost of imported raw materials and equipment needed by the company so that the increased production costs and vice versa for companies that export. The theory is based on the hypothesis studies suggest there is a direct influence of the movement of the rupiah against operating expenses. H3: There is a significant relationship between exchange rate movements directly toward operating expenses.

Theories about the effect of revenue and profits through research conducted by Efilia (2014) and Suryanto T (2016) has stated revenues significantly influence corporate profits. The theory is based on the hypothesis studies suggest there is a direct influence between revenues on profits. H4: There is a significant relationship between revenues directly on corporate earnings.

Theories about the effect of charges, harmonization of accounting and profit results of research conducted by Efilia (2014) and Suryanto, T (2016) has stated the cost of business did not significantly affect corporate profits. The theory is based on the hypothesis studies suggest there is no direct influence between operating expenses to earnings. H5: There is a significant relationship between direct operating expenses of corporate profits.

Theories about the effect of exchange rate changes on profit indirectly through the income shown by research conducted by the Perdana et.al (2012) the weakening exchange rate of the rupiah against the US dollar significantly affect the increase of export value, which means that the weakening of the exchange rate has impact on increasing revenue and profit due to an increase in export value. The theory is based on the research hypothesis suspect there is an influence indirectly between changes in the exchange rate to profits through revenue. H6: There is a significant relationship between changes in the exchange rate indirectly to the company's profit through revenue.

Theories about the effect of exchange rate changes indirectly to earnings through cost has been demonstrated by the statement of Rachman (2012: 9) states that for companies that import at the time of the decline of the rupiah against foreign currencies increases the cost of imported raw materials and equipment which required the company to increase production costs and vice versa for companies that export. Based on the theory 
research hypothesis suspect there is an influence indirectly between changes in the exchange rate on profits through biaya.H7: There is indirectly influence the exchange rate movements on the company's profit through revenue.

\section{RESEARCH METHODOLOGY}

The research variables have been divided into three, among others, the independent variable (X) exchange rate, the dependent variable is the profit of the company. Intervening variable is the income and expenses of the company. The exchange rate indicates the price or value of a country's currency into another country's currency value. The exchange rate can be defined as the amount of domestic money is needed, namely the amount of rupiah that is needed to obtain one unit of foreign currency. Sukirno (2012: 397). Revenues are inflows of other assets or increase of the assets or settlement of liabilities from the delivery of goods, provision of services, or any other activity which is the main operating company or central operations. Cost is defined as the outflow of assets or any other use of the assets or the liabilities caused by delivery or manufacture of goods, provision of services, or any other activity which is the main operating company or a central operations (Hery, 2015: 41). The gain or loss is the result of cost reductions on the company's revenue to generate profits if revenue exceeds expenses and otherwise the excess will result in a loss if the cost is greater than the total revenue (Samryn, 2014: 43).

The research method was used descriptive quantitative research with data collected and expressed and described in terms of numbers. This study serves to identify the influence of the variables $\mathrm{X}$ and $\mathrm{Y}$ influence between the movement of the rupiah against the net income of the sub sectors of food and beverages with revenues and cost of doing business as an intervening variable.

Operationalization of variables, the dependent variable is the net profit during the current year first quarter period of 2012 to 2015 third quarter. Net profit variable data has been measured in Rupiah denoted by Y. The intervening variable is the income and expenses, income that has been used is the operating revenues and costs used are contained operating expenses in the income statement of each company during the period in 2012 first quarter up to 2015's third quarter. Variable data revenues and expenses have been measured in rupees. The independent variable is the change in the exchange rate is the exchange rate or middle rate on each expiry of the current period during the first quarter of the period 2012 to 2015 third quarter. Variable data rate has been measured in Rupiah denoted by X.

Types and Sources of Data research was time series data in 2012 first quarter to the third quarter 2015 that is data revenues, operating expenses and net income of the financial statements of each company which has been published in the official website of Indonesia Stock Exchange (www.idx. co.id). Data exchange rate of Rupiah to US dollars has been obtained from Bank Indonesia to access the official website of Bank Indonesia (www.bi.go.id).

The study population was selected private company sub-sectors of food and beverages listed on the Indonesia Stock Exchange. Samples using purposive sampling technique are two companies manufacturers of processed food marine products where export-oriented companies, namely PT Sekar Bumi Tbk and PT Sekar Laut Tbk using data-quarter period in 2012 first quarter to 2015 the 3rd quarter of each company, the number of observations have been (n) as many as 30. the respondent company has been 
chosen because it has a larger export volume compared to the volume of domestic sales and has had a financial report for the first quarter period of 2012 until the third quarter of 2015 is complete and clear.

Object of research has been elected a net profit of sub-sectors of food and beverages to measure the effect of the exchange rate movements on net profit directly and indirectly through business income and business expenses. The research data is the value of the rupiah against the US dollar and net profit of the company. Data exchange rate obtained via the Internet to access the official website of Bank Indonesia (www.bi.go.id) in December 2015. Besides the collection of data and information is done by taking of a number of journals, articles, books, and internet.

Data analysis techniques have been using linear regression analysis, path analysis and classical assumption using the statistical program SPSS v.22. To measure the effect of changes in the exchange rate on profits is directly used by the regression equation: $Y=a+$ $\mathrm{bX}+\mathrm{e}$, description: $\mathrm{Y}=$ profit (net income) $\mathrm{X}=$ the exchange rate, revenues, costs; $\mathrm{a}=$ constant; $b=$ regression coefficient of each variable; $\mathrm{e}=$ the confounding variable.

Testing the effect of intervening variables have been using path analysis method which is an extension of the multiple linear regression analysis or path analysis using regression analysis to estimate the causal relationships between variables predetermined by the theory (Ghozali, 2006: 174-175). Path analysis was used to estimate the direct and indirect relationships between two variables. A direct relationship occurs when one variable affects other variables without any third variables that mediate the association of independent variables and the dependent variable. Indirect relationships occur if there is a third variable that mediates the relationship between the two variables. So the path analysis has been used to measure the relationship directly and indirectly between the dependent variable and independent variables through an intervening variable. The total effect of the relationship of variable $\mathrm{X}$ to $\mathrm{Y}$ is equal to the direct influence of variable $\mathrm{X}$ to $\mathrm{Y}$ (or regression coefficient path p1) plus the indirect effect (path or regression coefficient p2) multiplied by the coefficient or regression path $\mathrm{p} 3$.

Classic assumption test as multicollinearity, autocorrelation test classic assumption is the prerequisite test on parametric statistics to obtain an approximate value of an unbiased and efficient from a multiple linear regression equation. Multicolinierity test is used to test whether the regression model found a correlation between independent variables. A good regression model should not happen correlation between the independent variables. To detect the presence or absence of multicollinearity in the regression model are as follows: R2 value generated by an empirical regression model estimation is very high individually independent variables many do not significantly affect the dependent variable. Analyzing the correlation matrix of the independent variables. If there is a correlation between variables is quite high, generally above 0.90 , then this is an indication of multicollinearity. The absence of a high correlation between the independent variable does not mean free from multicollinearity. Multicolinearity can also be observe from the value of tolerance and variance inflation factor (VIF). Both these measurements indicate each independent variable Which explained by other independent variable. A data is said to have no symptoms multikolinieritas if $\mathrm{VIF}<10$ and has a number Tolerance $>$ $10 \%$. Based on the research that has been done with reference to those rules, has obtained results show the value of Tolerance no independent variables that have a value of Tolerance is less than 0.10 , meaning there is no correlation between the independent variables are worth more than $95 \%$. The result of the calculation of the value (VIF) also 
showed the same thing no one independent variable which has VIF value of more than 10 . The results show that the correlation between the independent variables remain below $90 \%$ it can be said does not happen multikolinieritas. So we can conclude that there is no multicollinearity between independent variables in the regression model.

Autocorrelation test was to test whether the linear regression model was no correlation between bullies error in period $t$ with bullies error in period $t-1$. If there has been a correlation, then there is a problem called correlation. A good regression model is a regression that is free from autocorrelation. To detect the symptoms of autocorrelation has been testing the Durbin-Watson (d). Durbin-Watson test is used only for autocorrelation level one and requires the intercept (constant) in the regression model, and there is no lag between the independent variables. The calculation result Durbin-Watson (d) compared with the value dtabel at $\alpha=0.05$. Based on the testing that was done DW values obtained at 1,390. Durbin-Watson value table for a significance level of 5\%, the number of samples $30(\mathrm{n})$ and the number of independent variables $3(\mathrm{k}=3)$ was 1.21 for the lower limit $(\mathrm{dl})$ and 1.65 for the upper limit (du). Because the value $\mathrm{dw}$ dl 1,390 greater than 1.21 and less than $1.65 \mathrm{du}$ so based decision-making autocorrelation concluded that there was no decision so do test Run Test to detect autocorrelation. SPSS output results indicate that the probability of 0.094 is greater than $\alpha=0.05$, which means that no autocorrelation between residual value.

Heteroscedasticity test was aimed at testing whether the regression model occurred inequality residual variance of the observations to other observations. If the variance from one observation to another observation remains then called and if different Homoscedastic called Heteroscidasticity. A good regression model is that Homoskedaticity or did not happen Heteroscedasticity. How to detect the presence or absence of heteroscedasticity is to see a graph of the plot between the predicted value of the dependent variable is ZPRED with residual SRESID. Basic analysis to measure whether there is heteroscedasticity is if there is a specific pattern, such as dots form a specific pattern of regular, wavy, widens, then narrows, then the indicate has occurred of heteroscedasticity. If there is no clear pattern, as well as the points spread above and below the number 0 on the $\mathrm{Y}$ axis, then there is no heteroscedasticity. Based on the test has been obtained scatterplot graph, dots randomly spread and spread both above and below the number 0 on the Y axis concluded that it had not occurred heteroscedasticity in regression models, so the regression model is used to predict a decent net profit based on the data of independent variables.

Normality test was aimed to test whether the regression model, or residual confounding variables normal distribution. There have been two ways to detect whether or not residual normal distribution with a graphical analysis and statistical tests. In the analysis of the chart to see the residual normality is to look at the graph histogram and normal probability plots. The normal distribution will form a straight diagonal line, and plotting the data will be compared with the residual diagonal lines. If the residual data distribution is normal, then the line that represents the actual data will follow a diagonal line. In principle normality can be detected by looking at the deployment point on a diagonal axis of the graph or to view the histogram of the residual. If the data is spread around the diagonal line and follow the direction of the diagonal line or histogram graph showing a normal distribution pattern, then the regression model to meet the assumption of normality. If the data are spread far from the diagonal and does not follow the direction of the diagonal line and the histogram or graph does not show normal distribution pattern, then the regression model did not meet the assumption of normality. Based on the test 
results have been obtained histogram graph that has a normal distribution pattern. Normal graph plots have dots spread around the diagonal line, and its distribution follows the direction of the diagonal line, the regression model to meet the assumption of normality. Normality test charts can be misleading if not carefully visually look normal, so the statistical analysis necessary to complete the analysis graphs in order to avoid mistakes in analyzing the test results. Simple statistical tests can be performed by non-parametric statistical tests Kolmogorov-Smirnov (K-S). Tests Kolmogorov-Smirnov 0.181 has demonstrated significant value greater than 0.05 , which means that the data residual has normal distribution. These results wereconsistent with previous trials.

Statistical hypothesis testing techniques have been used to determine whether the independent variable changes in exchange rates have a significant effect on the dependent variable net income. The statistical test used was the $t$ test, $F$ test, and the coefficient of determination (r2). According to Sanusi (2013: 122) The main function of the correlation analysis is to determine how closely the relationship between one variable with another variable. Measure that states the closeness of the relationship is the correlation coefficient using Pearson Product Moment. The Pearson correlation coefficient is worth -1 to +1 . The statistical test $t$ basically shows how far the influence of the independent variables individually predict the dependent variable (Ghozali, 2006: 84). Decision-making has been partially based on the probability value obtained from the processing of data through SPSS, if the probability $>0.05$ then Ho is accepted. If the probability $<0.05$ then Ho is rejected. At $t$ test, probability values can be seen in the results of the processing of SPSS output table column coefficient significance. F statistical test has been basically indicates whether all the independent variables in the model have influence smoking together on the dependent variable (Ghozali, 2006: 84). Simultaneous decision-making has also been based on the probability value obtained from the processing of data through SPSS, if the probability $>0.05$ then Ho is accepted. If the probability $<0.05$ then Ho is rejected. In test $\mathrm{F}$, the probability values can be seen in the results of the processing of SPSS output of the ANOVA table columns significance.

The coefficient of determination $\left(\mathrm{R}^{2}\right)$ essentially measures how far the ability of the model to explain variations in the dependent variable. The coefficient of determination is between zero and one. $\mathrm{R}^{2}$ value is small means that the ability of the independent variables in explaining the variation of the dependent variable is very limited. A value close to the mean of independent variables provide almost all the information needed to predict the variation of the dependent variable. In general, the coefficient of determination crossection data is relatively low because there is a great variation between each observation, while for the time series data usually has a high coefficient of determination. The fundamental weakness of the use of the coefficient of determination is biased against the number of independent variables included in the model. Each additional one independent variable, then $\mathrm{R}^{2}$ would rise no matter whether these variables significantly influence the dependent variable. Therefore, many researchers advocate for the use of adjusted $\mathrm{R}^{2}$ value when evaluating where best regression model. Unlike $\mathrm{R}^{2}$, Adjusted $\mathrm{R}^{2}$ can go up or down if the independent variable is added to the model (Ghozali, 2006: 83).

\section{RESULTS AND DISCUSSION}

Research on the exchange rate and earnings, these two variables have a relationship that occurs directly or indirectly. Indirectly the exchange rate may affect earnings through 
operating revenues and operating expenses. The exchange rate indicates the price or value of a country's currency expressed in another country's currency (Sukirno, 2012: 397). In this study, the rupiah against the US dollar has been used as a reference the average company into the currency effect on profit.

Influence or relationship between the exchange rate to the actual income has been raised by some studies that have been done before the conclusions as a reference. As expressed by Requeena and Walker (2005: 231) in the journal entitled "The impact of exchange rate Fluctuation on profit margins: The UK Car Market" has concluded that corporate profits are affected by changes in currency exchange rates. The statement also revealed by Baggs, Beaulieu, and Fung (2008) in the journal entitled "The Impact of Real Exchange Rate Movements on Service Sector Firms" journal has found significant implications for exchange rate fluctuations significantly affect the acquisition of the amount of the company's profits. based on the conclusion of several studies that have been done can be explained that exchange rate movements that occurred has had an influence on corporate profits.

Indirectly, the exchange rate has also affected earnings through operating revenues and operating expenses. In the export-oriented company, volatile exchange rate movements that have affected the company's operating revenue on export sales, as expressed by Perdana et.al (2012) that the weakening exchange rate of the rupiah against the US dollar significantly affect the increase in export value, means depreciation has impacted the increase in revenue and profit due to no increase in export value. Based on the conclusions of these studies has been explained by the increase in export value will increase returns on the sale of foreign companies thus indirectly affect profit or profit companies. It is associated with the company undertaking export activities, because companies that are exporting or trading in overseas have been using foreign currency as a means of transaction.

The exchange rate has become one of the factors that influence profit company with the movement of the exchange rate fluctuation effect, positive or negative, as said by Mann (in Ekawati, 2012: 39) stated that the change in the exchange rate will be absorbed into the profit, will ultimately affect a company.

Effect of exchange rate on profits has been proven on the company's export and import perpetrators. When doing sales companies using foreign currencies US dollars that can be accepted by all countries in the world. Fluctuations in exchange rates have made changes to the company's profit. If the exchange rate of the Rupiah against the US dollar has weakened, it can lead to increased acceptance of profit for the company exporters. When the exchange rate of Rupiah strengthened, it can make the acquisition of profit decline. This has happened because if the rupiah weakens, the greater the amount of amount received by the company to the US Dollar, and vice versa happens if the exchange rate of the rupiah currency has been strengthening. Fact news article in 2013 weakening of the rupiah against the US dollar does not always have a negative impact. For exporters of marine products had a positive impact conditions. According to the news statement stating that the weakening rupiah has had a positive impact on the company processed shrimp exporters for the difference in the exchange rate of the US dollar (www.kontan.co.id). The explanation has been added to the belief that the exchange rate can indeed affect the company's profit for exporters. Although not entirely of exchange rate movements affect the company's profit, but the companies in this study, especially the use of foreign 
currency as a means of transaction, the exchange rate has become one of the factors that may affect the profitability of the company.

Results and Discussion direct influence of variable $\mathrm{X}$ to variable $\mathrm{Y}$ using simple linear regression analysis to determine the effect had been directed as follows: Effect directly between the exchange rate to profits, obtained $\mathrm{Y}=-34420461613.761+$ $4476469.448+\mathrm{X}$, where $\mathrm{Y}=$ Profit ; $\mathrm{X}=$ Exchange Rate; Based on the regression equation, the value $-34420461613,761$ is a constant showing no effect of exchange rate variable or the value is zero, then the value of profit of $\mathrm{Rp}-34420461613,761$. While the value 4476469.448 a regression coefficient of the exchange rate variable (X) that indicates if the exchange rate variable increases in this case is the weak exchange rate causes a high amount value of $\mathrm{Rp} \mathrm{1,} \mathrm{-} \mathrm{then} \mathrm{the} \mathrm{profit} \mathrm{will} \mathrm{increase} \mathrm{by} \mathrm{Rp} 4476469.448$. These results have no direct influence between exchange rate movements with which the company's profit if the exchange rate weakening corporate profits will increase and vice versa, if the exchange rate strengthened.

The direct effect of the exchange rate on business income $\mathrm{Y}=-530841941862.627+$ 92325543.068 X; where: Y = Revenue; X = Exchange Rate; Based on the regression equation, the value $-530841941862,627$ a constant value which showed no influence of variable exchange rate or the value is zero, then the value of revenue of $\mathrm{Rp}$ 530841941862,627 . While the value of 92325543,068 is the regression coefficient of the exchange rate variable $(\mathrm{X})$ which shows that if the variable rate increases in this case is the weak exchange rate that causes the value of the high amount of $\mathrm{Rp} 1$, - then the revenues will increase by $\mathrm{Rp} 92325543,068$. From these results have proven that there is direct influence of the exchange rate movement with which the company's operating revenues if the rupiah weakens the company's operating revenues will increase and vice versa, if the exchange rate strengthened.

Directly influence the exchange rate against the operating expenses $+\mathrm{Y}=$ 66502274753.946 + 10951771.301 X; where: $\mathrm{Y}=$ Operating Expenses; $\mathrm{X}=$ Exchange Rate; The regression equation has stated value $-66502274753,946$ a constant value which showed no influence of variable exchange rate or the value is zero, then the value of operating expenses by $-66502274753,946$. While the value of regression coefficient 10951771.301 is the exchange rate variable $(\mathrm{X})$, shows that if the variable rate rises; weakening of the rupiah which causes a high amount value of $\mathrm{Rp} 1$, - the operating expenses will increase by Rp 10951771,301. These results have proved that there is direct influence of the exchange rate movement with operating expenses, if the rupiah weakens the operating expenses will increase and vice versa, if the exchange rate strengthened.

The direct effect between operating revenues and operating expenses to earnings was $\mathrm{Y}=-8703765839.501+0.057 \mathrm{X} 1-0.080 \mathrm{X} 2$; where: $\mathrm{Y}=$ Profit; $\mathrm{X} 1=$ Operating Revenues; $\mathrm{X} 2$ = Operating Expenses. Based on the regression equation, states that the value $-8703765839,501$ is a constant value that indicates if there is no influence of variable operating revenues and operating expenses or the value is zero, then the profit value of $-8703765839,501$. While 0057 is the regression coefficient value of the variable income (X1) which indicates if the variable operating revenues increased by $\mathrm{Rp} 1$, - then the profit will increase by $\mathrm{Rp} 0057$. And value - 0080 is the regression coefficient variable operating expenses (X2) which indicates if the variable operating expenses increased by $\mathrm{Rp} 1$, - then the profit will decrease by $\mathrm{Rp} 0.080$. The results have shown that there is an influence directly between operating revenues and operating expenses, when revenue 
increases, the company's profit will increase, while operating expenses increased if the corporate profits will decline.

Table 1. The Effect of Exchange Rates Directly to Profit

\begin{tabular}{lcccccccccc}
\hline Variable & $\mathrm{R}$ & Sig. & $\mathrm{N}$ & $\mathrm{Df}$ & $\mathrm{t}$-test & $\mathrm{t}$-table & Sig. & Beta & Constant & Hypotesis \\
\hline $\begin{array}{l}\text { Exchange } \\
\text { rate }\end{array}$ &, 368 & 0,045 & 30 & 28 & 2,097 & 2,048 &, 045 & 4476469,448 & $-34420461613,761$ & $\begin{array}{l}\mathrm{H}_{0}: \text { :rejected } \\
\mathrm{H}_{\mathrm{a}} \text { :accepted }\end{array}$ \\
\hline
\end{tabular}

Source: Results of Data Processing (2015).

Table 1 has shown a correlation coefficient of 0.368 with a significance level of 0.045 , which means the relationship between the movement of the exchange rate with the profit of the sub sectors of food and beverages is weak, because it is at $\pm 0.2- \pm 0.39$. The value of significance $0.045<0.05$, so it was concluded that the relationship between the two variables is significant direction. Variable rupiah $(\mathrm{X})$ has a value of regression coefficient of 4,476,469.448 and variable $X$ t value of 2.097 with $28 \mathrm{df}$, then the value $t$ table at the $95 \%$ confidence level $(\alpha=0.05)$ was 2.048 . Because the value of $t$ test $>t$ table and sig $(0,045)<\operatorname{sig}(0.05)$ it has been concluded that Ho is rejected, it means that exchange rate movements are directly significant effect on the profitability of companies sub-sector of food and beverages. These results are in accordance with the theory expressed by Requeena and Walker (2005: 231) in his journal that the profits of companies affected by movements in currency exchange rates, mean income is affected by the strengthening or weakening of the currency. Based on test results obtained by determination coefficient of 0.136 or $13.6 \%$. The results showed that the variable profit is affected by the exchange rate directly by $13.6 \%$ and the remaining $86.4 \%$ profit variable is influenced by other variables that are not included in this research model.

Table 2. The Effect of Exchange Rate against Direct Revenue

\begin{tabular}{lcccccccccc}
\hline Variable & $\mathrm{R}$ & Sig. & $\mathrm{N}$ & $\mathrm{Df}$ & $\mathrm{t}$ test & $\mathrm{t}$ table & Sig. & Beta & Constant & Hypotesis \\
\hline $\begin{array}{l}\text { Exchange } \\
\text { rate }\end{array}$ &, 439 &, 015 & 30 & 28 & 2,588 & 2,048 &, 015 & 92325543,068 & $-530841941862,627$ & $\begin{array}{l}\mathrm{H}_{0}: \text { rejected } \\
\mathrm{H}_{\mathrm{a}} \text { :accepted }\end{array}$ \\
\hline
\end{tabular}

Source: Data Processing (2015).

Table 2 has informed the correlation coefficient of 0.439 with a significance level of 0.015 means the relation of exchange rate movements with the acquisition of the company's operating income sub-sectors of food and drinks quite strong because they are at $\pm 0.4- \pm 0.59$. The value of significance $0.015<0.05$ so it was concluded that the relationship between the two variables is significant direction. Variable rupiah $(\mathrm{X})$ has a value of regression coefficient of 92,325,543.068 and variable $X$ t value of 2.588 with 28 $\mathrm{df}$, then the value t table at the $95 \%$ confidence level $(\alpha=0.05)$ was 2.048 . Because the value of $t$ test $>t$ table and sig (0.015) <sig (0.05) it can be concluded that Ho is rejected, which means that exchange rate movements are directly significant effect on the company's operating income sub-sectors of food and beverages. These results are in accordance with the results of research by Perdana et.al (2012) that a weakening exchange rate of the rupiah against the US dollar significantly affect the increase in export value, means of exchange rate depreciation can increase revenues and profit due to an increase in export value. Based on the test results have been obtained determination coefficient of 0.193 or $19.3 \%$. The results showed that the variables influenced revenue directly variable 
exchange rate amounted to $19.3 \%$ and the remaining $80.7 \%$ variable operating revenues are influenced by other independent variables which are not included in this research model.

Table 3. The Effect of Exchange Rates Directly against Fees

\begin{tabular}{lcccccccccc}
\hline Variable & $\mathrm{R}$ & Sig. & $\mathrm{N}$ & $\mathrm{Df}$ & $\mathrm{t}$ test & $\mathrm{t}$ table & Sig. & Beta & Constant & Hypotesis \\
\hline $\begin{array}{l}\text { Exchenge } \\
\text { rate }\end{array}$ &, 579 &, 001 & 30 & 28 & 3,760 & 2,048 & 0,001 & 10951771,301 & $-66502274753,946$ & $\begin{array}{l}\mathrm{H}_{0}: \text { rejectd } \\
\mathrm{H}_{\mathrm{a}}: \text { acceptd }\end{array}$ \\
\hline
\end{tabular}

Source: Data Processing (2015).

Table 3 inform correlation coefficient of 0.579 with a significance level of 0.001 means that the relationship between exchange rate movements with operating expenses of food and beverage sub-sector has been quite strong, because it is at $\pm 0.4- \pm 0.59$. The value of significance $0.001<0.05$ so it was concluded that the relationship between these two variables significantly searah.Variabel rupiah $(\mathrm{X})$ has a value of regression coefficient of 10,951,771.301 and variable $\mathrm{X}$ t value of 3.760 with $28 \mathrm{df}$, then the value $\mathrm{t}$ table on 95\% confidence level $(\alpha=0.05)$ was 2.048. Because the value of t count $>$ t table and sig $(0.001)$ <sig (0.05) it can be concluded that Ho was rejected, which means that exchange rate movements have been directly significant effect on operating expenses sub-sectors of the food and minuman.Hasil in accordance with that expressed by Rachman (2012: 9) that the movement of the fluctuating exchange is good for companies that import or export.

Table 4. The Effect of Operating Revenues to Profit

\begin{tabular}{lcccccccccc}
\hline \multicolumn{1}{c}{ Variable } & $\mathrm{R}$ & Sig. & $\mathrm{N}$ & $\mathrm{Df}$ & $\mathrm{t}$ test & $\mathrm{t}$ table & Sig. & Beta & Constant & Hypotesis \\
\hline $\begin{array}{l}\text { Business } \\
\text { Income }\end{array}$ &, 914 & 0,000 & 30 & 28 & 10,073 & 2,048 & 0,000 & 0,057 & $-8703765839,501$ & $\begin{array}{l}\mathrm{H}_{0}: \text { accepted } \\
\mathrm{H}_{\mathrm{a}}: \text { rejected }\end{array}$ \\
\hline
\end{tabular}

Source: Data Processing (2015).

Table 4. shows the correlation coefficient of 0.914 with a significance level of 0.000 means that the relationship between revenues with profit companies food and beverage sub-sector has been particularly strong because they are at $\pm 0.8- \pm 1$. The value of significance $0.000,0.05$ thus concluded that the relationship between these two variables have signifikan. Variabel income $(\mathrm{X})$ is worth a regression coefficient of 0,057 and t value of the variable $X 10,073$ with df 28 , then the value t table at a rate of $95 \%(\alpha=0.05)$ was 2.048. Because the value of $t$ test $>t$ table and sig $(0,000)<\operatorname{sig}(0.05)$, we conclude that Ho was rejected, meaning revenues are directly significant effect on the company's profit sub-sectors of food and beverages. These results are in accordance with Efilia study (2014) found a significant effect on operating revenues of corporate profits.

Table 5. The Effect of Cost to Profi

\begin{tabular}{lcccccccccc}
\hline Variabel & $\mathrm{R}$ & Sig. & $\mathrm{N}$ & $\mathrm{Df}$ & $\mathrm{t}$ test & $\mathrm{t}$ table & Sig. & Beta & Constant & Hypotesis \\
\hline $\begin{array}{l}\text { Business } \\
\text { costs }\end{array}$ &, 513 &, 004 & 30 & 28 & $-1,262$ & 2,048 &, 218 & $-0,080$ & $-8703765839,501$ & $\begin{array}{l}\mathrm{H}_{0}: \text { accepted } \\
\mathrm{H}_{\mathrm{a}}: \text { :rejected }\end{array}$ \\
\hline
\end{tabular}

Source: Data Processing (2015). 
Table 5 shows the correlation coefficient of 0.513 with a significance level of 0.004 means that the relationship between operating expenses with the acquisition of the company's profit food and beverage sub-sector has been quite strong, because it is at \pm 0.4 - \pm 0.59 . The value of significance $0.004<0.05$ so it was concluded that the relationship between the two variables was significant. Variable operating expenses $(\mathrm{X})$ has a value of regression coefficient of -0.080 and $t$ value of -1.262 variable $X$ with $\mathrm{df} 28$, the value of $t$ table at the $95 \%$ confidence level $(\alpha=0.05)$ was 2.048. Because the value of $t<t$ table and sig (0.218)> sig (0.05), we conclude that Ho had been accepted, meaning direct operating expenses did not significantly affect the company's profit sub-sectors of food and beverages. These results was in accordance with the results of research Efilia (2014) that operating expenses had no significant effect on corporate earnings.

Table 6. The Simultaneous Effect of Operating Revenues and Expenses to Profit

\begin{tabular}{lcccccccccc}
\hline Variables & $\mathrm{R}$ & Sig. & $\mathrm{N}$ & $\mathrm{Df}$ & $\mathrm{F}$ test & F table & Sig. & Adj. $\mathrm{R}^{2}$ & Constant & Hypotesis \\
\hline $\begin{array}{l}\text { Operating } \\
\text { revenues } \\
\text { and fees }\end{array}$ &, 919 &, 000 & 30 & 27 & 73,680 & 3,35 &, 000 &, 834 & $-8703765839,501$ & $\begin{array}{l}\mathrm{H}_{0}: \text { accepted } \\
\mathrm{H}_{\mathrm{a}}: \text { rejected }\end{array}$ \\
\hline
\end{tabular}

Source: Data Processing (2015).

According to Table 6 correlation coefficient of 0.919 with a significance level of 0.000 means that the relationship between operating revenues and operating expenses with the profit of the sub sectors of food and beverages simultaneously has been very strong, because it is at $\pm 0.8- \pm 1$. The value of significance $0.000<0.05$ so it has been concluded that the relationship between the two variables simultaneously significant. Variable operating revenues and operating expenses simultaneously have calculated $\mathrm{F}$ value of 73.680 with $27 \mathrm{df}$, then the value of $\mathrm{F}$ table at the $95 \%$ confidence level $(\alpha=0.05)$ was 3.5. Because the F test $>\mathrm{F}$ table and $\operatorname{sig}(0,000)<\operatorname{sig}(0.05)$, we conclude that Ho was rejected, meaning the operating revenues and operating expenses simultaneously has significant effect on corporate earnings subsectors of food and beverages. Based on test results obtained by the value of determination coefficient of 0.834 or $83.4 \%$. These results has indicated that the variable profit has been affected by the variable operating revenues and operating expenses simultaneously at $83.4 \%$ and the remaining $16.6 \%$ profit variable influenced or explained by other independent variables which were not included in this research model.

The Effect of Exchange Rate Not Directly Against Profit hypothesis exchange rate directly affects the profit (p1), however, also hypothesized that the exchange rate has an indirect effect on earnings with an indirect relationship as follows: The exchange rate affects revenues (p2), then affect earnings (p3). The exchange rate affects operating expenses ( $\mathrm{p} 4)$, then affect earnings (p5). The regression equation for the direct influence of the exchange rate and profit previously been tested. So as to analyze the relationship between these variables have required three regression equation as follows: a) Income = $\mathrm{b} 1+\mathrm{e} 1$ exchange rate; $\mathrm{b})$ Operating Expenses $=\mathrm{b} 1+$ Exchange $+\mathrm{e} 2$ and $\mathrm{c}$ ) Operating Revenues Profit $=\mathrm{b} 2+$ Operating Expenses $+\mathrm{e} 3$. Based on the testing that was done, the obtained results SPSS output as follows.

Table 7. The Prove of IndirectRelationships (equation 1)

\begin{tabular}{ccccc}
\hline Variable & $\mathrm{N}$ & Sig. & $\mathrm{R}^{2}$ & Coefficient of Standardized Beta \\
\hline Exchange rate & 30 &, 015 &, 193 &, 439 \\
\hline
\end{tabular}


Source: Data Processing (2015).

Based on Table 7 it could be observed that the standardized beta coefficient values obtained 0,439 which is a path or line $2(\mathrm{p} 2)$. The R2 in equation 1 is equal to 0.193 so that the value of e1 $=\sqrt{ }((1-0,193))=0.898$.

Table 8.The Prove of IndirectRelationships (equation 2)

\begin{tabular}{ccccc}
\hline Variable & $\mathrm{N}$ & Sig. & $\mathrm{R}^{2}$ & $\begin{array}{c}\text { Coefficient of } \\
\text { Standardized Beta }\end{array}$ \\
\hline Exchange Rate & 30 &, 001 &, 335 &, 579 \\
\hline
\end{tabular}

Source: Data Processing (2015).

According to Table 4.7 shows that the standardized beta coefficient values obtained 0,579 which is a path $4(\mathrm{p} 4)$. The value of $\mathrm{R} 2$ in equation 2 is equal to 0.335 so that the value of e $2=\sqrt{ }((1-0,335))=0.815$.

Table 9.The Prove of IndirectRelationships (Equation 3)

\begin{tabular}{llccc}
\hline \multicolumn{1}{c}{ Variables } & $\mathrm{N}$ & Sig. & $\mathrm{R}^{2}$ & $\begin{array}{c}\text { Coefficient of } \\
\text { Standardized Beta }\end{array}$ \\
\hline $\begin{array}{l}\text { Operating revenues } \\
\text { Business costs }\end{array}$ & 30 & .000 & & .994 \\
\hline Source: Data Processing & 30 &, 263 &, 845 &,- 128 \\
\hline
\end{tabular}

Source: Data Processing (2015).

The Table 8 shows that there has been standardized beta coefficient values obtained operating revenues of value 0.994 path 3 (p3). For the standardized beta coefficient -0.128 operating expenses as a value line 5 (p5). The R2 in the equation 3 is equal to 0.845 so that the value $\mathrm{e} 3=\sqrt{ }((1-0,845))=0.393$.

The results of path analysis has shown that the exchange rate has a direct effect on earnings and may also affect indirectly from profit to operating income as an intervening later to profit. The indirect effect has also been shown from profit to operating expenses and then to profit.

Table 10.The Total Effect of Exchange Rates to Profit

\begin{tabular}{lc}
\hline \multicolumn{1}{c}{ Influence } & Value \\
\hline 1. Direct Influence & 0,368 \\
2. Indirect Influence: & \\
The exchange rate to revenues into profits & $0,439 \times 0,994=0,436$ \\
The exchange rate to charge to profit & $0,579 \times-0,128=-0,074$ \\
Total Influence & 0,73
\end{tabular}

Source: Data Processing (2015).

From the calculation of the indirect effect of exchange rate on profits through an intervening variable operating revenues and operating expenses, has been obtained for the total effect of exchange rates on profits by summing the direct and indirect effects of the result by 0.73 . 


\section{DISCUSSION}

The result showed the value of a direct influence with regression coefficient variable exchange rate amounted to 4,476,469.448 significance value of 0.045 , we conclude exchange rate movements may directly affect the company's net income for the period sub-sectors of food and beverages. The conditions in accordance with the results of Requeena and Walker (2005: 231) in his journal stating that the profits of companies affected by movements in currency exchange rates, meant that earnings are affected by the strengthening or weakening of the currency.

From earlier calculations had acquired a significance value of 0.045 between the exchange rates to profits directly, meaning there is the influence or relationship ushered both variables although not too strong. The exchange rate is not the only factor affecting the company's profitability, but the exchange rate is also a factor to consider in export and import company.

This study has been said to be significant because it uses an export-oriented company, selling more abroad than domestic and a foreign currency in the transaction, so it has the influence of the movement of the exchange rate with the profit of the company.

Significance analysis of SPSS has been done not solely based on calculations but also on the theories, journals, statements in the research that has been done before and articles that support that indeed there is the influence of the exchange rate to profits directly.

The test results directly influence the exchange rate of revenues was obtained regression coefficient value exchange rate amounted to $92,325,543.07$ with a significance value of 0.015 , so it has been concluded that exchange rate movements may directly affect the company's operating revenues sub-sectors of food and beverages. These results are in accordance with the results declared by Perdana et.al (2012) that the weakening exchange rate of the rupiah against the US dollars significantly affects the increase in the value of exports, which means that the weakening of the exchange rate may have an impact on the increase in revenue and profit for an increase in export value.

Results of testing the effect of the exchange rate directly to operating expenses have been obtained regression coefficient value exchange rate amounted to 10,951,771.30 with a significance value of 0.001 so it has been concluded that exchange rate movements may directly affect the operating expenses of food and beverage sub-sector. These results are consistent with the findings Rachman (2012: 9) that the movement of the fluctuating exchange is good for companies that import or export.

Results of testing the effect of operating revenues directly to the company's profit has been obtained regression coefficient operating revenue of 0.057 with a significance value of 0.000 so it has been concluded that the revenues may affect the company's profit sub-sectors of food and beverages. These results are in accordance with the findings of Efilia (2014) found a significant effect on operating revenues of corporate profits.

From the above calculations have been obtained significance value of 0.000 between the revenues to profits directly, meaning there is a strong influence between the two variables. If the exchange rate weakened the revenue on the company's overseas sales will increase.

But the results of testing the influence of operating expenses against earnings the company has obtained the regression coefficient variable operating expenses amounting to -0.080 with a significance value of 0.218 , has concluded that the cost of business did not 
affect the company's profit sub-sectors of food and beverages. These results are consistent with the theory Efilia (2014) which states that the cost of doing business no significant effect on corporate profits. From the above calculation obtained significance value of 0.218 between revenues on profits directly which means there is no influence or relationship between the two variables for significance value greater than $\alpha=0.05$.

The test results of path analysis has been obtained by the value that exchange rate movements can affect directly or indirectly through intervening variables, in this study interveningnya variable is the operating revenues and operating expenses of the company. From the calculation of the path analysis results obtained directly influence the exchange rate against a profit of 0.368 , while for the effect of indirectly such as the effect of exchange rates on earnings through operating revenues amounted to 0.436 and the indirect influence of the exchange rate on earnings over operating expenses amounted to - 0,074. So for the total effect of the exchange rate on profits is by adding together the effects of direct and indirect effect and the total effect is obtained by 0.73 .

The results of this study have revealed significant because this study used an exportoriented company, to do more foreign than domestic sales and the use of foreign currency in the transaction, so it has the influence of the movement of the exchange rate with the profit of the company.

Significance SPSS analysis results are not solely the calculations, but based on the theories, journals, statements in the research that has been done before and articles that support that indeed there is the influence of the exchange rate to profits directly.

From the results of these studies confirmed that there keterpengaruhan profit company by exchange rate movements for the studied company has export volume of more than $90 \%$ and the rest is domestic sales. When the movement of the exchange rate weakening of the profits earned on the proceeds abroad. Besides the production company uses the main raw material comes from domestic, given the company uses raw materials of marine products, and Indonesia is a country that has many marine products, so companies do shopping with Rupiah and selling foreign currency. So the weakening of the rupiah can positively impact export-oriented domestic companies, among others, can increase the value of exports will further increase the profitability of the company.

Back to the problem of this research, according to a statement in a news article in 2013 about the impact of the weakening rupiah has expressed the weakening of the rupiah against the US dollar does not always have a negative impact. For exporters of marine products such conditions had a positive impact. According to the news statement has stated that the weakening rupiah positive impact on the company processed shrimp exporters for the difference in the exchange rate of the US dollar. Besides theories and research that has been done before, the news related to the discussion of issues become a factor in the study.

Factors exchange rate has been very influential, because the studied company is export-oriented enterprises, using foreign currency in their transactions. It has become one of the reasons why these effects occur because if the company does not undertake export activities it will be difficult to prove the existence of such influence.

\section{CONCLUSION}

(1) Directly exchange rates have a significant effect on the company's profit sub-sectors of food and beverages.(2) Directly exchange rates have a significant effect on operating 
expenses sub-sectors of food and beverages. (3) Direct revenue had a significant effect on the company's profit sub-sectors of food and beverages. (4) Direct operating expenses did not significantly affect profit sub-sectors of food and beverages.

Based on path analysis test has been obtained that the exchange rate can affect directly and can also be influenced indirectly. Has been obtained for the total effect of exchange rates on profit amounted to 0.73. Based on the statistical test and the test directions of exchange rate movements has directly significant and positive impact on earnings, meaning that a weak exchange rate has led to high-value amount can raise the profitability of the company. Based on the statistical test and the test directions of exchange rate movements has directly significant and positive impact on revenue, means weakening of the exchange rate has led to a high amount can increase the value of the company's operating revenues. Based on the statistical test and the test directions of exchange rate movements has directly significant and positive impact on business costs, meaning a weak exchange rate has caused the value of the rupiah will increase the costs of business enterprises. Based on statistical tests and test operating revenues directly toward significant and positive impact on earnings, meaning if revenues increase, the profit will increase. Based on statistical tests and test directly toward the cost of business did not affect the profit.

\section{SUGGESTION}

(1) Companies can pay attention to the movement of exchange rate changes are uncertain because the exchange rate is one factor that is considered in the company's business activities. (2) Subsequent research, in order to increase the period of time to see the effect of exchange rate movements in depth so that the measured effect can be measured precisely. (3) Subsequent research in order to use more samples so that research results become more valid and clear.

\section{BIBLIOGRAPHY}

Ainul, Fitri. (2008) “Analisis Pengaruh Nilai Tukar Terhadap Net Income dan Return Saham Perusahaan Manufaktur yang Terdaftar di Bursa Efek Indonesia Periode 2003-2006". Skripsi. Fakultas Ekonomi. Depok: Universitas Indonesia.

Baggs, J., Beaulieu, Fung. (2008) The Impact of Real Exchange Rate Movements on Service Sector Firm.

Badan Pembinaan Hukum Nasional (BPHN). (2009) Laporan Kegiatan Analisa dan Evaluasi tentang Lintas Devisa dan Sistim Nilai Tukar.

Efilia, Meiza. (2014) "Pengaruh Pendapatan Usahadan Beban Operasional Terhadap laba bersih pada perusahaan kimia dan Keramik, porselin \& kaca yang terdaftar di bursa efek indonesia periode 2008-2012”. E-journal. hal: 13.

Ekananda, Mahyus. (2014) Ekonomi Internasional. Jakarta: Erlangga.

Ekawati, Rani.(2012) "Analisis Penagruh Fluktuasi Nilai Tukar terhadap Profit PT Timah Tbk". Skripsi. Fakultas Ekonomi dan Bisnis. Jakarta: Universitas Pancasila.

Ghozali, Imam. (2006) Aplikasi Analisis Multivariate dengan Program SPSS. Semarang: Badan Penerbit UNDIP. 
Hady, Hamdy. (2012) Manajemen Keuangan Internasional. Jakarta: Mitra Wacana Media.

Hasanah, U., Danang S. (2013) Pengantar Ilmu Ekonomi Makro. Jakarta: CAPS

Hery. (2015) Analisis Laporan Keuangan. Yogyakarta: CAPS

Hirmawan, Aditya. (2013) Eksportir Udang Diuntungkan Pelemahan Rupiah. http://industri.kontan.co.id/news/eksportir-udang-diuntungkan-pelemahanrupiah. Diakses pada 28 November 2015.

Kewal, Suramaya .S. (2012) "Pengaruh Inflasi, Suku Bunga, Kurs, dan Pertumbuhan PDB Terhadap Indeks Harga Saham Gabungan”. Jurnal Economia. Vol: 8.

Mankiw, N.G. (2006) Macroeconomics, 6th edition. (Diterjemahkan oleh: Fitria Liza). Jakarta: Erlangga.

Manullang, Sumanto Gi. (2008) "Analisis Pengaruh Nilai Tukar Terhadap Impor Kapas di Indonesia”. Tesis. Fakultas Ekonomi. Depok: Universitas Indonesia.

Patel et.al. (2014) "Factors Affecting Currency Exchange Rate, Economical Formulas and Prediction Models". International Journal of Aplication or Inovation in Engineering \& Management. Volume 3.hal: 53.

Perdana, D., Yaningwati, F., Saifi, M. (2014) "Pengaruh Pelemahan Nilai Tukar Mata Uang Lokal (IDR) Terhadap Nilai Ekspor”. Jurnal Administrasi Bisnis. Vol.17.hal:7.

Rachman, P.P. (2012) “Analisis Pengaruh Variabel Makro Terhadap Return Indeks Sembilan Sektor Pada Bursa Efek Indonesia". Tesis. Program Studi Magister Manajemen. Depok: Universitas Indonesia.

Samryn, L.M. (2014) Pengantar Akuntansi: Mudah Membuat Jurnal Dengan Pendekatan Siklus Transaksi. Jakarta: Rajawali Pers.

Sanusi, Anwar. (2013) Metodologi Penelitian Bisnis. Jakarta: Salemba Empat.

Requena, Silvente F and Walker, J. (2007) "The Impact Of Exchange Rate Fluctuation On Profit Margin: The UK Car Market, 1997-2002”. Journal of Applied Economics. Vol: X.

Sugiyono. (2010) Metode Penelitian Bisnis ( Pendekatan Kuantitatif, Kualitatif, dan $R \& D)$. Bandung: Alfabeta

Sugiyono. (2013) Metode Penelitian Bisnis ( Pendekatan Kuantitatif, Kualitatif, dan $R \& D)$. Bandung: Alfabeta.

Sukirno, Sadono. (2012) Makroekonomi Teori Pengantar. Jakarta: Rajagrafindo Pers.

Tambunan, Tulus T.H. (2015) Perekonomian Indonesia Era Orde Lama Hingga Jokowi. Bogor: Ghalia Indonesia.

Undang-Undang No. 24 tentang Lalu Lintas Devisa dan Sistim Nilai Tukar.

www.idx.co.id

www.bi.go.id 